\title{
Earnings Management, Internal Control and Audit Pricing
}

\author{
Zixuan Wang ${ }^{1, a}$ \\ ${ }^{1}$ Beijing Jiaotong University, China \\ azixuanwang0406@gmail.com
}

Keywords: earnings management, internal control, audit pricing, audit risk, audit cost

\begin{abstract}
This paper analyzes the relationship between earnings management, internal control and audit pricing with a sample of A-share listed companies in Shanghai and Shenzhen for the period 2009 through 2016.The data of internal control are obtained from DIB internal control index. The modified Jones model is used to measure the earnings management. The audit pricing is a surrogate variable of audit pricing. The results suggest that the correlation between internal control and audit pricing is negative, earnings management has a significant positive impact on audit pricing, and the lower the internal control level, the more positive impact of earnings management on audit pricing.
\end{abstract}

\section{Introduction}

Audit pricing is the audit fee, which is the price given by the accounting firm and the enterprise for the audit service. In the determination of the factors affecting audit pricing, scholars have reached a basic unity, that is, audit pricing is mainly determined by audit costs and audit risks (Simunic,1980; Francis, 1984; Firth, 1985) [1,2,3]. According to the cost-benefit principle, the increase in audit costs will inevitably lead to an increase in audit fees. At the same time, the risk-return principle tells us that higher audit risks will be accompanied by higher audit fees. Gul and Tsui examined the relationship between agency costs and audit pricing. Their study found that there is a positive correlation between the controllable earnings and the audit pricing (Gul, et al., 1997) [4]. Defond and Subramanyam found that the higher the amount of discretionary earnings, the greater the risk of litigation faced by auditors and the higher the audit fees (Defond et al., 1998) [5]. The internal control system plays an important role in regulating business operations and preventing risks. Simunic believes that CPAs can reduce the scope of substantive testing of external audits for companies with higher internal control quality, and audit pricing is also reduced (Simunic, 1980). Another view is that companies with high internal control quality, management will attach great importance to the internal control of the company, and will hire an accountant who can represent high-quality audit in order to ensure the good reputation of the company (Eichenseher and Shields, 1985) [6]. The audit was conducted (Pincus et al., 1989) and was willing to pay a high audit fee (Hay et al., 2006) $[7,8]$.

Therefore, I focus on the following questions: Does a relatively sound internal control system have an impact on audit pricing? Do the earnings management and internal control affect the audit pricing and how? Under different internal control levels, will there be a difference in the relationship between earnings management and audit pricing?

The next section develops theory and hypotheses concerning the relation among the Earnings management, internal control and audit pricing. Section 3 describes the sample selection and research design. Section 4 discusses empirical results and analysis. The last section explains conclusions and comes up to some recommendations.

\section{Theory and empirical hypotheses}

Audit Pricing, which is the pricing of audit services, consists of three parts: firstly, the various expenses that must be spent to complete the audit project accountant, that is audit costs; secondly, possible legal disputes and the loss of the legal liability to be borne by, this is the risk cost; thirdly, the profit required to maintain the normal operation of the accounting firm. [9] 


\subsection{Earnings management and audit pricing}

The general earnings management behavior of enterprises is usually hard to be perceived and increases the risk of auditing. In addition, the objects of earnings management usually have relatively strong uncertainty, which makes it easy to operate. Therefore, earnings management will greatly increase the risk of auditing. According to the principles of market risks and corresponding benefits, the audit costs should be increased.

The complexity and diversity of corporate earnings management lead auditors to increase audit procedures during the audit process, while investing more time and labor to better identify the company's earnings management. This will increase audit costs. Audit pricing will also increase based on cost-effectiveness principles. Therefore, I propose Hypothesis 1.

Hypothesis 1: The higher the degree of corporate earnings management, the higher the auditing firm's audit pricing.

\subsection{Internal control and audit pricing}

Under the sound internal control system, the credibility of the financial statements of enterprises has increased, and the audit risk has been reduced. This makes CPAs no longer increase their testing efforts because of audit risks. (Houstonetc.2005) [10] Instead, they will reduce the substantive testing procedures accordingly to reduce audit costs, so audit fees will decrease. The higher the internal control level, the lower the audit cost. And good external governance environment will promote the relationship between the two. Therefore, I propose Hypothesis 2.

Hypothesis 2: The higher the internal control level of the firm, the lower the auditing firm's audit pricing.

\subsection{Earnings management, internal control and audit pricing}

Audit pricing mainly depends on audit cost and audit risk, but the impacts on audit costs and audit risk are not equal under different conditions. Generally speaking, if the internal control level of the enterprise is high, the system will inhibit the management and reduce the opportunities for the executives to speculate. Thereby the audit risk of the CPAs will be reduced. At this point, audit pricing is more dependent on audit costs than audit risks, and vice versa.

CPAs tend to use the company's earnings management to measure the size of their audit risk and adjust the level of audit fees. For companies with higher earnings management, the audit fees are higher. Based on this, we propose Hypothesis 3 and Hypothesis 4.

Hypothesis 3: The lower the level of internal control, the more significant the positive correlation between earnings management and audit pricing.

Hypothesis 4: The higher the level of internal control, the weaker the positive correlation between earnings management and audit pricing.

\section{Research methodology}

\subsection{Sample selection}

This study uses a sample of the listed companies from Shanghai and Shenzhen for the period 2009 through 2016. In order to ensure the accuracy of the research results, the following samples were excluded: (1) Excluding financial and insurance listed companies; (2) Excluding companies with ST and ST* during the sample period; (3) Excluding financial data missing or abnormal sample. The internal control data used are derived from the internal control index library published by DIB, and the rest data are obtained from CSMAR.

\subsection{Variable definitions}

\subsubsection{Explained variable}

This paper selects the public logarithm of the publicly disclosed audit fees (LNFEE) to measure audit pricing. 


\subsubsection{Estimating the degree of earnings management}

Referring to the practice of most scholars in China, this paper uses the accrual profit separation model to estimate the level of earnings management of accrued projects. Defond et al. (1995) and Subramanyam (1996) found that the Jones model based on industry-specific cross-section correction accurately measures the manageability accruals [11]. In addition, Roychowdhury (2006) argue that the modified Jones model that considers performance can better estimate the degree of corporate earnings management [12]. Therefore, this paper uses the modified Jones model considering performance to estimate the sample company's accrued project earnings management level, and uses its absolute value to measure the company's earnings management.

Total accrual profit (TA):

$$
T A_{i, t}=N I_{i, t}-C F O_{i, t} .
$$

Where $T A_{i, t}$ is the total accrued profit of the company $i$ in year $t . N I_{i, t}$ is the net profit of the company $i$ in year $t$. CFO $O_{i, t}$ is the net cash flow from operating activities profit of the company $i$ in year $t$. Each variable is divided by the total assets at the end of $t-1$ year to standardize to eliminate the impact of company size differences on the research results.

Nondiscretionary accruals (NDA):

$$
N D A_{i, t}=\alpha_{0}+\alpha_{1} \frac{1}{A_{i . t-1}}+\alpha_{2} \frac{\Delta R E V_{i, t}-\Delta R E C_{i, t}}{A_{i, t-1}}+\alpha_{3} \frac{P P E_{i, t}}{A_{i, t-1}}+\alpha_{4} R O A_{i, t-1}
$$

Where $N D A_{i, t}$ is the non-manipulative accruals. $\triangle R E V_{i, t}$ is the changes in operating income.. $\triangle R E C_{i, t}$ is is the changes in accounts recevable. $P P E_{i, t}$ is the total value of fixed assets. $R O A_{i, t}$ is the return on total assets ratio. $A_{i, t-1}$ is the total assets. The parameters $\alpha_{0}, \alpha_{1}, \alpha_{2}, \alpha_{3}$, and $\alpha_{4}$ in the model (2) are estimated using the industry cross-section data by the following formula:

$$
T A_{i, t}=b_{0}+b_{1} \frac{1}{A_{i . t-1}}+b_{2} \frac{\Delta R E V_{i, t}-\Delta R E C_{i, t}}{A_{i . t-1}}+b_{3} \frac{P P E_{i, t}}{A_{i, t-1}}+b_{4} R O A_{i, t-1}+\varepsilon_{i, t} .
$$

Discretionary Accruals (DA):

$$
D A_{i, t}=T A_{i, t}-N D A_{i, t} .
$$

This paper uses the absolute value of discretionary accruals (ABSDA) to measure the degree of earnings management.

\subsubsection{Estimating the degree of internal control level}

This paper uses DIB internal control index to measure internal control level. The index is an internal control index system that combines qualitative and quantitative evaluation methods to reflect the internal control level and risk management and control capabilities of Chinese listed companies. If the internal control index of the sample company is higher than the median, the internal control level is high, and vice versa.

\subsubsection{Control variables}

Referring to the literature on the factors affecting the audit fees, such as the company's financial status, corporate governance and auditor characteristics,this paper selects the following control variables: the scale of the audited company (LNSIZE), asset-liability ratio (LEV), return on equity (ROE), Current ratio (CR), audit opinion type (OPINION), firm size (BIG4), corporate growth (GROWTH), accounts receivable and inventory to total assets ratio (IRISK), shareholding ratio of the largest shareholder (TOP), the switch of the firm (SWITCH). The annual dummy variable (YEAR) and the industry dummy variable (INDUSTRY) are added to the model to control the macro factors and business cycles of different years and the impact of different industry attributes.

\subsection{Model design}

\subsubsection{Basic tests}

This study examines the ralationships between earnings management, internal control and audit pricing. We first investigate whether there is a corralation between earnings management and audit pricing. The regression to test Hypothesis 1 is estimated as follows: 


$$
\begin{aligned}
& \operatorname{LNFEE}_{i, t}=\beta_{0}+\beta_{1} \mathrm{ABSDA}_{i, t}+\beta_{2} \operatorname{LNSIZE}_{i, t}+\beta_{3} L E V_{i, t}+\beta_{4} \mathrm{CR}_{i, t}+\beta_{5} \operatorname{ROE}_{i, t}+\beta_{6} \text { OPINION }_{i, t}+\beta_{7} \text { BIG }_{i, t} \\
& +\beta_{8} \text { GROWTH }_{i, t}+\beta_{9} \text { IRISK }_{i, t}+\beta_{10} \text { TOP }_{i, t}+\beta_{11} \text { SWITCH }_{i, t}+\sum Y E A R+\sum I N D U S T R Y+\varepsilon_{i, t}
\end{aligned}
$$

Then, I introduce an alternative variable IC of internal control level to test the impact of the internal control level on audit pricing to test Hypothesis 2. The regression is estimated as follows:

$$
\begin{aligned}
\text { LNFEE }_{i, t} & =\beta_{0}+\beta_{1} I_{i, t}+\beta_{2} \text { LNSIZE }_{i, t}+\beta_{3} L_{E V} V_{i, t}+\beta_{4} C_{i, t}+\beta_{5} \text { ROE }_{i, t}+\beta_{6} \text { OPINION }_{i, t}+\beta_{7} \text { BIG }_{i, t} \\
& +\beta_{8} \text { GROWTH }_{i, t}+\beta_{9} \text { IRISK }_{i, t}+\beta_{10} \text { TOP }_{i, t}+\beta_{11} \text { SWITCH }_{i, t}+\sum Y E A R+\sum I N D U S T R Y+\varepsilon_{i, t}
\end{aligned}
$$

Finally, based on the level of internal control, the research sample is divided into high internal control level group and low internal control level group. Group test is carried out to further verify the influence of internal control on the relationship between earnings management and audit pricing. Hypothesis 3 and Hypothesis 4 are tested.

3.3.2 Robustness test

In order to ensure the robustness of the empirical results, this paper uses the extended Jones model proposed by Lu Jianqiao (1999) to conduct a robustness test. This model is used to replace the modified Jones model in the basic test to measure the earnings management level of the company's accruals[13]. The extended Jones model is a re-amendment of the modified Jones model, which takes into account the impact of intangible assets and other long-term assets on nondiscretionary accruals and can more accurately estimate the discretionary accruals.

$$
T A_{i, t}=b_{0}+b_{1} \frac{1}{A_{i . t-1}}+b_{2} \frac{\Delta R E V_{i, t}-\Delta R E C_{i, t}}{A_{i . t-1}}+b_{3} \frac{P P E_{i, t}}{A_{i . t-1}}+b_{4} \frac{I A_{i, t}}{A_{i . t-1}}+\varepsilon_{i, t}
$$

Where $I A_{i, t}$ is the total value of intangible assets and other long-term assets.

\section{Results}

\subsection{Descriptive statistic}

Descriptive statistics for the relevant data of the sample companies are shown in Table 1.

Table 1. Descriptive statistics

\begin{tabular}{ccccccc}
\hline variable & $\mathrm{N}$ & mean & $\mathrm{sd}$ & $\min$ & $\mathrm{p} 50$ & $\max$ \\
\hline LNFEE & 14621 & 13.54 & 0.757 & 9.210 & 13.43 & 18.37 \\
\hline ABSDA & 14621 & 0.0722 & 0.133 & 0 & 0.0444 & 6.297 \\
\hline IC & 14621 & 652.4 & 141.6 & 0 & 679.3 & 995.4 \\
\hline LNSIZE & 14621 & 21.93 & 1.359 & 10.84 & 21.78 & 28.51 \\
\hline LEV & 14621 & 0.539 & 2.576 & -0.195 & 0.463 & 142.7 \\
\hline CR & 14621 & 2.418 & 4.431 & -5.132 & 1.480 & 204.7 \\
\hline ROE & 14621 & 0.103 & 6.884 & -176.4 & 0.0693 & 713.2 \\
\hline OPINION & 14621 & 0.0381 & 0.191 & 0 & 0 & 1 \\
\hline BIG4 & 14621 & 0.0585 & 0.235 & 0 & 0 & 1 \\
\hline GROWTH & 14621 & 20.64 & 1579 & -1 & 0.105 & 134600 \\
\hline IRISK & 14621 & 0.270 & 0.179 & 0 & 0.245 & 0.945 \\
\hline TOP & 14621 & 35.89 & 15.61 & 0.290 & 33.85 & 89.99 \\
\hline SWITCH & 14621 & 0.0788 & 0.269 & 0 & 0 & 1
\end{tabular}

It can be seen from Table1 that the average of the logarithm of audit pricing is 13.54 and the gap between the maximum and the minimum is relatively large, which is related to the size, risk, etc. The reality is that there are large differences in terms of different audit fees. The minimum of earnings management is close to 0 , and the maximum is 6.297 , indicating that there is a big difference in the degree of earnings management among companies. The average internal control index is 652.4, the minimum and maximum values are 0 and 995.4 and the standard deviation reaches 141.6, indicating that the internal control levels of a sample company are very different and there is no high concentration. There is also a certain difference between the data of each control variable. 


\subsection{Regression analysis}

Multivariate regression of the full sample and internal control level grouping is performed Eq. 5 and Eq. 6. The results are shown in Table 2.

Table 2. Multiple regression results

\begin{tabular}{|c|c|c|c|c|}
\hline sample & \multicolumn{2}{|c|}{ Full sample } & \multirow{2}{*}{$\begin{array}{c}\text { High internal control } \\
(3)\end{array}$} & \multirow{2}{*}{$\begin{array}{c}\text { Low internal control } \\
(4)\end{array}$} \\
\hline regress & (1) & (2) & & \\
\hline Variables & LNFEE & LNFEE & LNFEE & LNFEE \\
\hline \multirow[t]{2}{*}{ ABSDA } & $0.0705^{*}$ & & -0.0286 & $0.0861^{*}$ \\
\hline & $(1.72)$ & & $(-0.38)$ & $(1.71)$ \\
\hline \multirow[t]{2}{*}{ IC } & & $-0.0001 * * *$ & & \\
\hline & & $(-2.87)$ & & \\
\hline \multirow[t]{2}{*}{ LNSIZE } & $0.373 * * *$ & $0.377 * * *$ & $0.431 * * *$ & $0.311^{* * *}$ \\
\hline & $(83.76)$ & $(80.49)$ & $(64.87)$ & (55.61) \\
\hline \multirow[t]{2}{*}{ LEV } & 0.0014 & -0.0104 & $-0.204 * * *$ & $0.127 * * *$ \\
\hline & $(0.06)$ & $(-0.42)$ & $(-5.01)$ & $(5.75)$ \\
\hline \multirow[t]{2}{*}{ CR } & $-0.0120 * * *$ & $-0.0122 * * *$ & $-0.0150 * * *$ & $-0.00961 * * *$ \\
\hline & $(-7.86)$ & $(-7.96)$ & $(-6.81)$ & $(-4.78)$ \\
\hline \multirow[t]{2}{*}{ ROE } & $-0.0693 * *$ & -0.0478 & -0.119 & -0.0110 \\
\hline & $(-2.42)$ & $(-1.59)$ & $(-1.52)$ & $(-0.51)$ \\
\hline \multirow[t]{2}{*}{ OPINION } & $0.225 * * *$ & $0.206 * * *$ & $0.136 * *$ & $0.140 * * *$ \\
\hline & $(10.97)$ & $(9.67)$ & $(2.36)$ & $(6.40)$ \\
\hline \multirow[t]{2}{*}{ BIG4 } & $0.811^{* * *}$ & $0.813^{* * *}$ & $0.799 * * *$ & $0.662 * * *$ \\
\hline & (37.51) & (37.54) & $(30.26)$ & $(20.44)$ \\
\hline \multirow[t]{2}{*}{ GROWTH } & $-0.0202 * * *$ & $-0.0184 * * *$ & $-0.0208 *$ & -0.0124 \\
\hline & $(-2.86)$ & $(-2.63)$ & $(-1.96)$ & $(-1.42)$ \\
\hline \multirow[t]{2}{*}{ IRISK } & -0.0092 & -0.00265 & $0.145^{* * *}$ & $-0.0857 * * *$ \\
\hline & $(-0.36)$ & $(-0.10)$ & (3.68) & $(-2.73)$ \\
\hline \multirow[t]{2}{*}{ TOP } & $-0.0008 * * *$ & $-0.000797 * * *$ & $-0.000793 * *$ & $-0.000812 * *$ \\
\hline & $(-3.40)$ & $(-3.33)$ & $(-2.39)$ & $(-2.43)$ \\
\hline \multirow[t]{2}{*}{ SWITCH } & $-0.0623^{* * *}$ & $-0.0634 * * *$ & $-0.0683^{* * *}$ & $-0.0566 * * *$ \\
\hline & $(-4.50)$ & $(-4.58)$ & $(-3.34)$ & $(-3.20)$ \\
\hline YEAR & YES & YES & YES & YES \\
\hline INDUSTRY & YES & YES & YES & YES \\
\hline \multirow[t]{2}{*}{ Cons } & $5.221 * * *$ & $5.224 * * *$ & $3.994 * * *$ & $6.510 * * *$ \\
\hline & $(55.96)$ & (56.13) & $(28.54)$ & (54.93) \\
\hline Adj.R2 & 0.6777 & 0.6779 & 0.7291 & 0.5996 \\
\hline $\mathrm{F}$ & $427.36 * * *$ & $426.96 * * *$ & $280.22 * * *$ & $194.45 * * *$ \\
\hline $\mathrm{N}$ & 14621 & 14621 & 7309 & 7312 \\
\hline \multicolumn{5}{|c|}{ t statistics in parentheses } \\
\hline \multicolumn{5}{|c|}{$* p<0.1, * * p<0.05, * * * p<0.01$} \\
\hline
\end{tabular}

Column (1) in Table1 indicates there is a positive correlation between earnings management and audit pricing. The coefficient associated with earnings management is significantly different from zero. Therefore, we conclude that the higher the degree of corporate earnings management, the higher the auditing firm's audit pricing (Hypothesis 1).

The coefficient of IC in column (2) is -0.0001, which is negative at the level of significance of $1 \%$, indicating that the company's audit fee will decrease correspondingly with the increase of internal control level, thus verifying hypothesis 2, i.e. the higher the internal control level of the firm, the lower the auditing firm's audit pricing. However, the value of the coefficient is very small, which indicates that the level of internal control may not affect the audit pricing.

It can be seen from column (4) that for companies with low internal control level, audit pricing and earnings management are significantly positively correlated at the level of $10 \%$, with a coefficient of 0.0861 , which is greater than the coefficient of the full sample in column (1) of 0.0705.Therefore, the hypothesis 3 is been verified, that is, the lower the level of internal control, the more significant the positive correlation between earnings management and audit pricing. For enterprises with high internal control level, audit pricing is negatively correlated with the degree of earnings management, and the significance test is not passed. Hypothesis 4 has not been verified. 
The results illustrate that compared with the audit cost, the level of audit pricing is more determined by the degree of earnings management of the audited entity, that is, the size of the audit risk. When CPAs are pricing an audit business, they first pay attention to the risk of the business for the accounting firm, whether it is a high-risk project, and secondly, pay attention to the complexity of the audit business, that is, how much labor cost should be invested. At the same time, combined with the objective factors such as the size of the company being audited, the audit fees will be finalized. It can be seen that accounting firms pay more attention to the losses that may be caused by high-risk projects when conducting audit pricing, rather than the cost of business complexity.

This robustness test mainly considers the impact of intangible assets and other long-term assets on uncontrollable accruals when calculating the degree of earnings management. There is no significant difference in the results. The results are not shown here.

\section{Conclusions}

This paper analyzes the relationship between earnings management, internal control and audit pricing with a sample of A-share listed companies in Shanghai and Shenzhen for the period 2009 through 2016. The results suggest that the correlation between internal control and audit pricing is negative, earnings management has a significant positive impact on audit pricing, and the lower the internal control level, the more positive impact of earnings management on audit pricing.

The internal control level has a significant negative impact on audit pricing. The sound internal control mechanism makes it impossible for external auditors to find problems from the system surface, therefore the auditors have to increase the audit input to explore the nature of the problem. A perfect internal control mechanism brings difficulties for external auditors and increases audit risk, so all Accounting firms may increase audit pricing to compensate for risks. The extent of its impact on audit pricing is small because many companies in real life have not implemented effective internal control systems.

There is a significant positive correlation between earnings management and audit pricing, which is consistent with previous research findings, because audit pricing depends on factors such as audit costs and audit risks. The existence of earnings management will not only increase the risk of audit failure, but also increase the audit procedures. Such high costs will inevitably lead to high audit fees, and audit pricing will therefore rise. For enterprises with low internal control level, the degree of earnings management is relatively high. At this time, the audit risk will increase substantially, and the testing intensity will also increase. According to the principle of cost-effectiveness and risk-return, audit fees will also increase. It can be seen from the above results that the CPA's audit pricing is first concerned with audit risk, followed by other factors such as audit costs.

\section{References}

[1] D. A. Simunic, The pricing of audit services: theory and evidence, Journal of Accounting Research, vol.18(1), pp.161-190,1980.

[2] J. R. Francis and D. T. Simon, The Effort of Auditing Firm Size on Audit Prices: A Study of the Australian Market, Journal of Accounting and Economics, vol.8, pp. 133-150, 1984.

[3] M. Firth, An Analysis of Audit Fees and their Determinants in New Zealand. Auditing, A Journal of Practice and Theory, vol.3, pp. 23-37,1985.

[4] F. A. Gul, J. Tsui and C. Chen, Agency costs and audit pricing, Evidence on discretionary accruals,1997.

[5] M. L. Defond and K. R. Subramanyamm, Auditor changes and discretionary accruals, Journal of Accounting \& Economics, vol.25(1), pp. 35-67,1998.

[6] J. W. Eichenseher and Shields, D. Corporate director liability and monitoring preferences, Journal of Accounting and Public Policy, vol.4(1), pp. 13-31,1985. 
[7] K. Pincus, Rusbarsky and J. Wong, Voluntary formation of corporate audit committees among NASDAQ firms, Journal of Accounting and Public Policy, vol. 8, pp. 239-65,1989.

[8] D. Hay, W. R. Knechel and N. Wong, Audit fees: A meta-analysis of the effect of supply and demand attributes, Contemporary Accounting Research, vol.23, pp. 141-92, 2006.

[9] W. Chi, L. L. Ling, and M. Pevzner, Is Enhanced Audit Quality Associated with Greater Real Earnings Management? Social Science Electronic Publishing, vol.25(2), pp. 315-335,2011.

[10]R. Hoitash, U. Hoitash and J. C. Bedard, Internal control quality and audit pricing under the Sarbanes-Oxley act Auditing, A Journal of Practice and Theory, vol.27(1), pp. 105-126, 2008.

[11]M. L. Defond and K. R. Subramanyamm, Auditor changes and discretionary accruals, Journal of Accounting \& Economics, vol.25(1), 1998.

[12]S. Roychowdhury, Earnings management through real activities manipulation, Journal of Accounting \& Economics, vol.42(3), pp. 335-370,2006

[13]L. Jianqiao, An Empirical Study on Earnings Management of Loss-Listed Companies in China, Accounting Research, vol.1999(9), pp. 25-35m,1999 